\title{
Medicinal Uses of Carica Papaya
}

\section{Anitha $\mathrm{B}^{2}$, Raghu N1, Gopenath TS³ ${ }^{3}$ Karthikeyan $\mathbf{M}^{4}$, Gnanasekaran $\mathrm{A}^{4}$, Chandrashekrappa $\mathrm{GK}^{5}$ and Basalingappa KM1* \\ ${ }^{1}$ Division of Molecular Biology, Faculty of Life Sciences, Jagadguru Sri Shivarathreeswara} (JSS) University, India

${ }^{2}$ Division of Biochemistry, Faculty of Life Sciences, Jagadguru Sri Shivarathreeswara (JSS) University, India

${ }^{3}$ Division of Biotechnology, Faculty of Life Sciences, Jagadguru Sri Shivarathreeswara (JSS) University, India

${ }^{4}$ Department of Microbiology, Faculty of Medicine, Quest International University Perak, Malaysia

${ }^{5}$ Chairman, Faculty of Life Sciences, Jagadguru Sri Shivarathreeswara (JSS) University, India

${ }^{*}$ Corresponding author: Kanthesh M Basalingappa, Division of Molecular Biology, Faculty of Life Sciences, JSS Academy of Higher Education \& Research, (Deemed to be University), SS Nagara, Mysuru-570015, India, Tel: 9482046281; Email: kanthu4001@gmail.com

\section{Abstract/Objective}

Medicinal plants have been used for various diseases traditionally in many countries, because of its advantages like easy availability, effective and economical in therapeutics. Carica papaya, also called as pawpaw is traditionally cultivated for fruit. Carica papaya belonging to the genus Carica. It contains the enzyme papain, chymopapain which is biologically active and has medicinal and nutritional values. All parts of the plant like leaves, fruits, seeds, flowers and roots can be used by humans as food and medicinal purposes. This plant has therapeutic uses like anti-amoebic, anti-microbial, anti fertility activity, anti-ulcerogenic, anti-fungal, antitumor, hypolipidaemic and employ in wound -healing activity, free radical scavenging activity, diuretic activity, uterotonic activity. In this review we have discussed details about papaya plant parts and its uses.

Keywords: Carica Papaya; Medicinal; Herb; Fruit

\section{Introduction}

Medicinal sources are easily and abundantly available in nature since time immemorial, herbal source of active ingredients helps in managing intractable diseases, for this reason trade of plant materials have been increased [1]. Herbs are gaining their position high as the synthetic drugs are unsafe and not good to environment, herbs are safe and secured to use and have qualities like aromatic, flavouring and medicinal properties. Hence, herbal renaissance is happening all over the globe [2]. All plant parts have medicinal values but the active components concentration varies from structure to structure [3]. These medicinal values lie in some chemical substances which alter physiological change in the body [4]. 


\section{Journal of Natural \& Ayurvedic Medicine}

Carica papaya is a plant belonging to family Caricaceae it is also called as pawpaw with potential medicinal values and has been cultivated in most of the tropical countries [5]. Carica papaya is a large tree like herbaceous perennial plant with soft single stem growing up to $5-10 \mathrm{~m}$ height, with sparely arranged leaves at the top of the trunk, lower trunk is scarred where leaves and fruits are born [4]. The plants are usually short-lived, but can produce fruits for more than 20years. The papaya has a complicated means of reproduction [6]. From thousands of years nature is giving us a source of medicinal plants, in which all parts of plants is used ( C. papaya) such as leaves, fruits, seeds, peel, roots, flowers [7]. It is cultivated for its fruits, throughout the world's tropical and subtropical regions [8]. It is originated from Southern Mexico, Central America and the northern part of South America [9].

Papaya is a berry type fruit with parietal placentation, it is well known for its food and nutritional values [10]. It is also called as "fruit of a common man", known as popular fruit [11]. Carica papaya Plant grows rapidly and have weak and soft stem which yields latex and have large and long stalked leaves. It usually branches when it is injured [4]. Papaya plants are dioeciously or hermaphroditic, producing only male, female or bisexual (hermaphroditic) flowers. Plant pollinate in three waysself-pollination or pollen from same plant but different flower or pollen from different flower [12] (Figure 1).

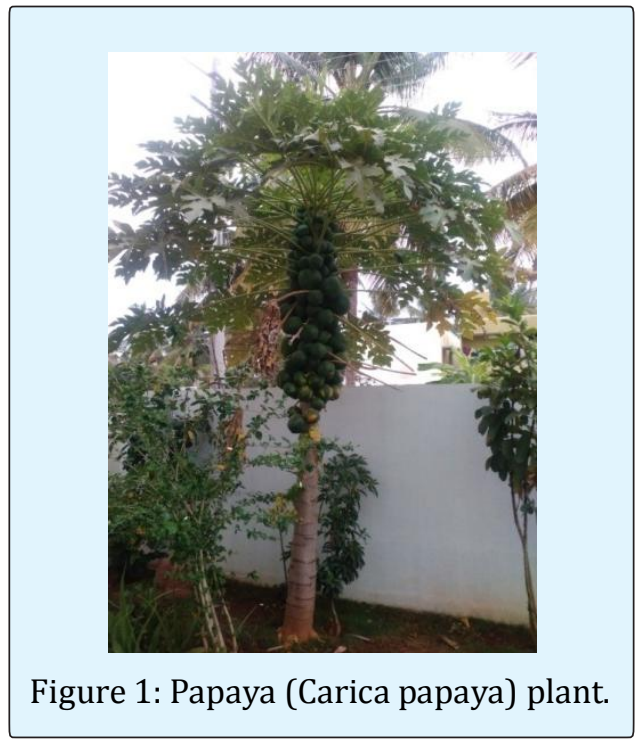

Papaya plant also has lactiferous properties. The specialized cells secrete latex in most of the tissues, secreted latex is dispersed thought the plant, and latex is a rich source of papain, chymopapain, caricain and glycol end peptidases [13]. Latex is a complex mixture of chemical compounds with diverse chemical activities collectively; these compounds are thought to be involved in defence system of the plants [14]. This herbaceous plant is also known as papaw, paw paw, kapaya, lapaya, tapaya, papayao, papaya, papaia, papita, lechosa, fruta bomba, mamon, mamona, mamao and tree melon [15]. Papaya leaves have shown the presence of anti-dengue, anti-plasmodia, anti-cancer, antibacterial, hepatoprotection, anti-inflammatory and Antioxidant properties in-vitro and in-vivo studies [16]. This plant has been used traditionally in cases of kidney failure, low sperm count, dental care, heart problems, natural memory enhancer, and remedy for fibroids in uterus [17] (Figure 2).

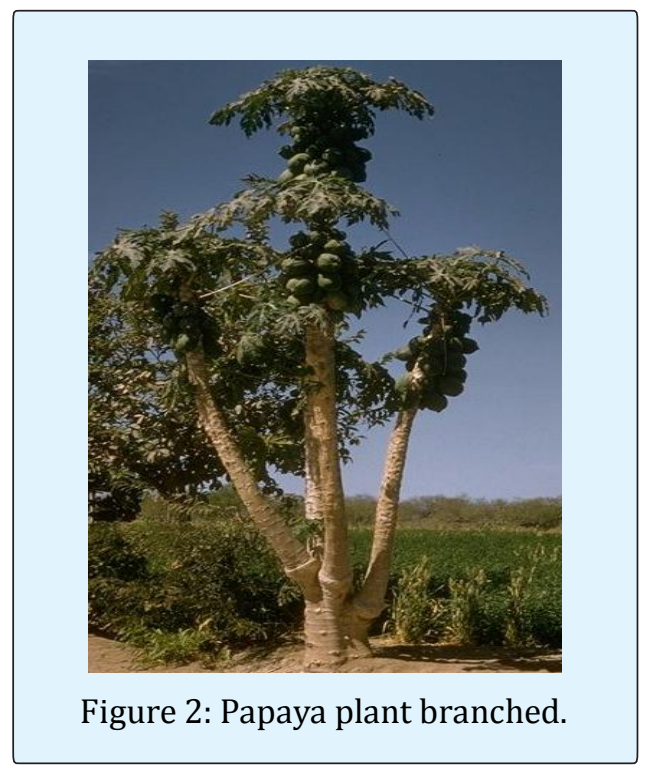

\section{Chemical Composition of Various Parts of Carica Papaya Linn}

- Fruit -protein, fat, fibre, carbohydrates, minerals, calcium, phosphorus, iron, vitamin C, thiamine, riboflavin, niacin, and caroxene, amino acid, citric acids and molic acid (green fruits), volatile compounds: linalol, benzylisothiocynate, cis and trans 2, 6-dimethyl3,6 expoxy-7 octen-2-ol. Alkaloid, $\alpha$; carpaine, benzyl- $\beta$ d glucoside, 2-phenylethl- $\beta$-D-glucoside, 4-hydroxyl phenyl-2 ethyl-B-D glucoside and four isomeric malonated benzyl- $\beta$-D glucosides.

- Juice -N-butyric, n-hexanoic and n-octanoic acids, lipids; myristic, palmitic, stearic, linoleic, linolenic acids-vaccenic acid and oleic acids.

- Seed-Fatty acids, crude proteins, crude fibre, papaya oil, carpaine, benzylisothiocynate, benzylglucosinolate, 


\section{Journal of Natural \& Ayurvedic Medicine}

glucotropacolin, benzylthiourea, hentriacontane, $\beta$ sistosterol, caricin and an enzyme nyrosin.

- Root - Arposide and an enzyme myrosin.

- Leaves-Alkaloids carpain, pseudocarpain and dehydrocarpaine I and II, choline, carposide, vitamin C and $\mathrm{E}$.

- Bark $\beta$-sitosterol, glucose, fructose, sucrose, galactose and xylitol.

- Latex -proteolytic enzymes, papain and chymopapain, glutamine cyclotransferase, chymopapain A, B and C, peptidase A and B and lysozymes. Error! Bookmark not defined.

\section{Origin and Distribution}

- Carica papaya is believed to have originated in the lowlands of eastern Central America, from Mexico to Panama [18]. Some suggests South America as origin and some say Central America as centre of origin [19]. It is usually cultivated in the tropical and neo-tropical regions of the world between $32^{\circ}$ North and South.

- Even though papaya is believed to have been cultivated by early civilizations; no records are available prior to the arrival of Columbus in America [15].

- Papaya plant is grown in tropical and subtropical countries, which includes 57 counties like India, Brazil, Indonesia, Mexico and Nigeria.

- Among these countries India is the largest producer of papaya [18]. Its seeds were distributed to the Caribbean and south-east Asia during Spanish exploration in the $16^{\text {th }}$ Century, from where it spread rapidly to India, the Pacific and Africa [19] (Figure 3).

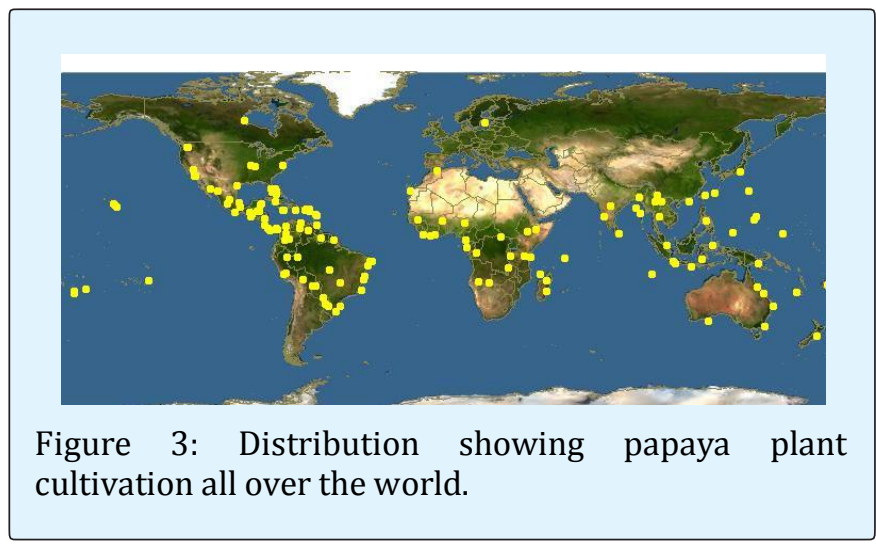

\section{Caricaceae Family have Six Genera Among which Carica is One}

- Only two species from Caricaceae under cyclicomorpha exists in Africa (C. Solmsii in West Africa and C. Parviflora in East Africa) which are large trees.
- all other species of Caricaceae family is distributed from new world Mexico to paraguay. jarilla which has three species spread from Mexico to guatemala.

- Jacartia having six species in it, is present from lowlands of south and central America,

- Vasconcella comprising highest species in it, about 20 species is present and a hybrid. These are found in Northern Andes.

- Other species is harovitzia having only one species is seen in Submontane Forests in Southern Mexico.

- The most important genus is Carica having only one species Papaya, Carica Papaya wild form occurs only in Mesoamerica from Southern Mexico to Costa Rica [20].

\section{Taxonomy}

Carica papaya belongs to family Caricaceae and this family consists of 34 species, one is hybrid from six genera [20]. The six genera as follows:

- Cyclicomorpha comprising 2 species- C. solmsii and C. parviflora

- Jarilla- 3 species J. heterophylla, J. caudata

- Jacaratia-7 species, three speciesadapted to dry areas (J. mexicana and J. corumbensis) and four to tropical rain forests (J. dolichaula, J. spinosa, J. digitate and J. chocoensis) [20].

- Vasconcellea-20 pecies- V. stipulata, $\mathrm{V} \times$ heilbornii V. weberbaueri, V. Parviflora, V. quercifolia, V. chilensis, V. candicans (+ V. crassipetala?) All other analyzed taxa (+ V. crassipetala) [21].

- Harovitzia and Carica consist of only one species- H. cnidoscoloides and Carica papaya each of which carica is economically important one, have papaya as speciesCarica papaya [22] (Table 1).

\begin{tabular}{|c|c|}
\hline Domain & Flowering plant \\
\hline Kingdom & Plantae \\
\hline Sub Kingdom & Tracheobionta \\
\hline Class & Magnoliopsida \\
\hline Subclass & Dilleniidae \\
\hline Super division & Spermatophyta \\
\hline Phylum & Steptophyta \\
\hline Order & Brassicales \\
\hline Family & Caricaceae \\
\hline Genus & Carica \\
\hline Botanical Name & Carica papaya \\
\hline
\end{tabular}

Table 1: Botanical Classification [12]. 


\section{Journal of Natural \& Ayurvedic Medicine}

\section{Morphology}

- Carica papaya is a dicotyledonous, polygamous and diploid species [9]. The papaya is a large perennial herb with a rapid growth rate. The plants are male or hermaphrodite or female [23].

- The papaya plant has an erect branchless, succulent and soft wooded trunk 6-20 feet (1.8-6.1 m) tall, and a palm like head of foliage at the top. They never develop true bark and the trunk marked scars from previous leaf stems and contains an acrid milky latex sap.

- The leaves are deeply incised and lobed [8]. Mature leaves are palmate with deep lobes and are supported by smooth and hollow petiole. The leaf scars given by petiole enlarge as the plant grows in circumference [15]. Fruits hang on short stalks in clusters directly from the trunk beneath the umbrella of giant leaves. Papayas flower and fruit simultaneously throughout the year [8] (Figure 4).

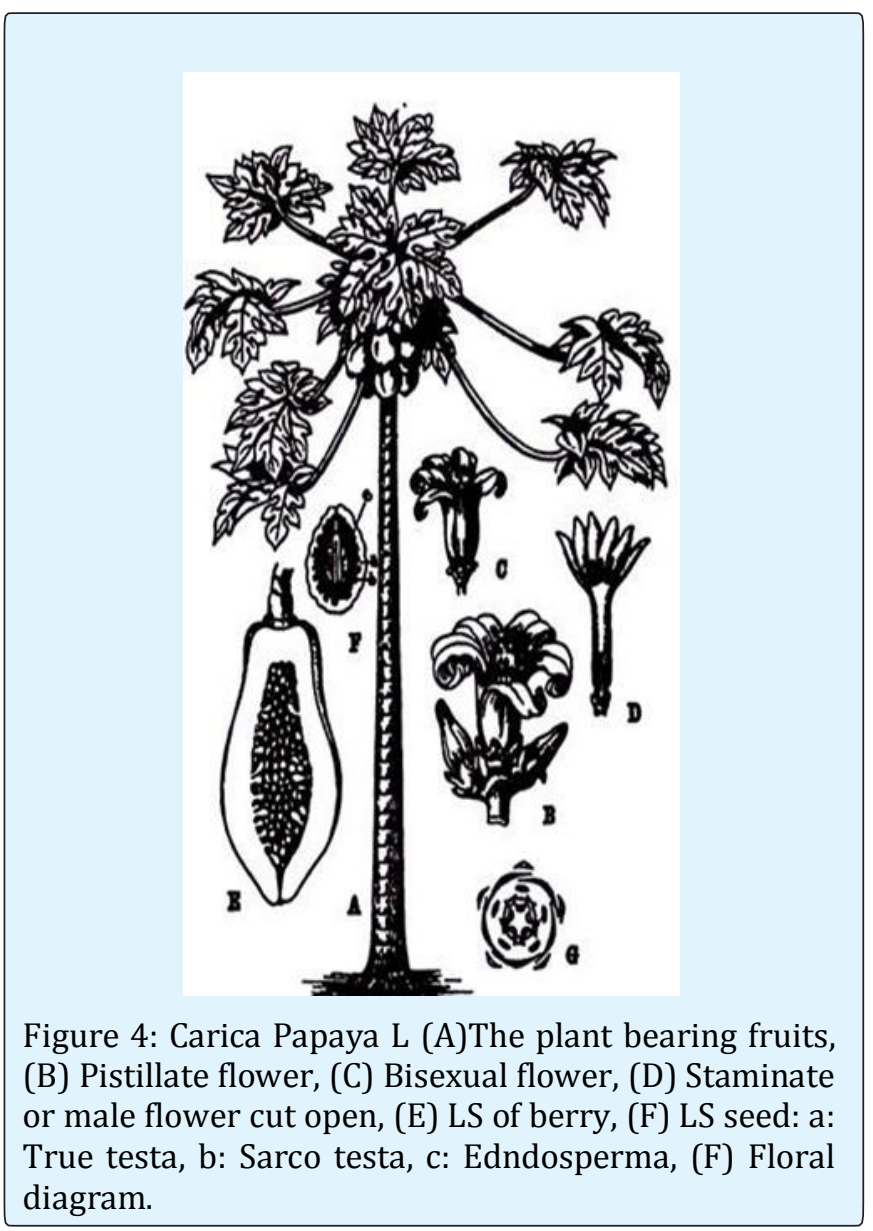

- The five-petal led flowers are fleshy, waxy and slightly fragrant. Papaya flowers are born on inflorescences [24]. Flowers appear on the axils of the leaves, maturing into the large 15-45 centimetre long, 10-30 centimetre diameter fruit. Its flowers are mostly dioecious and resemble each other until they start to develop sexual organs [2].

- Female flowers are held close against the stem as single flowers or in clusters of 2-3 [24]. Female flowers contain an ovary but lack pollen sacs, and they need to be pollinated.

- The hermaphroditic plants have flowers that contain both an ovary (female organ) and pollen sacs (male organ); they are self-pollinating. Hermaphroditic flowers are more uniformly tubular than female flowers, which are bulbous at the base and pointed at the end [25].

- Male flowers are smaller and more numerous and are born on $60-90 \mathrm{~cm}$ long pendulous inflorescences [19] (Figure $5 \& 6$ ).
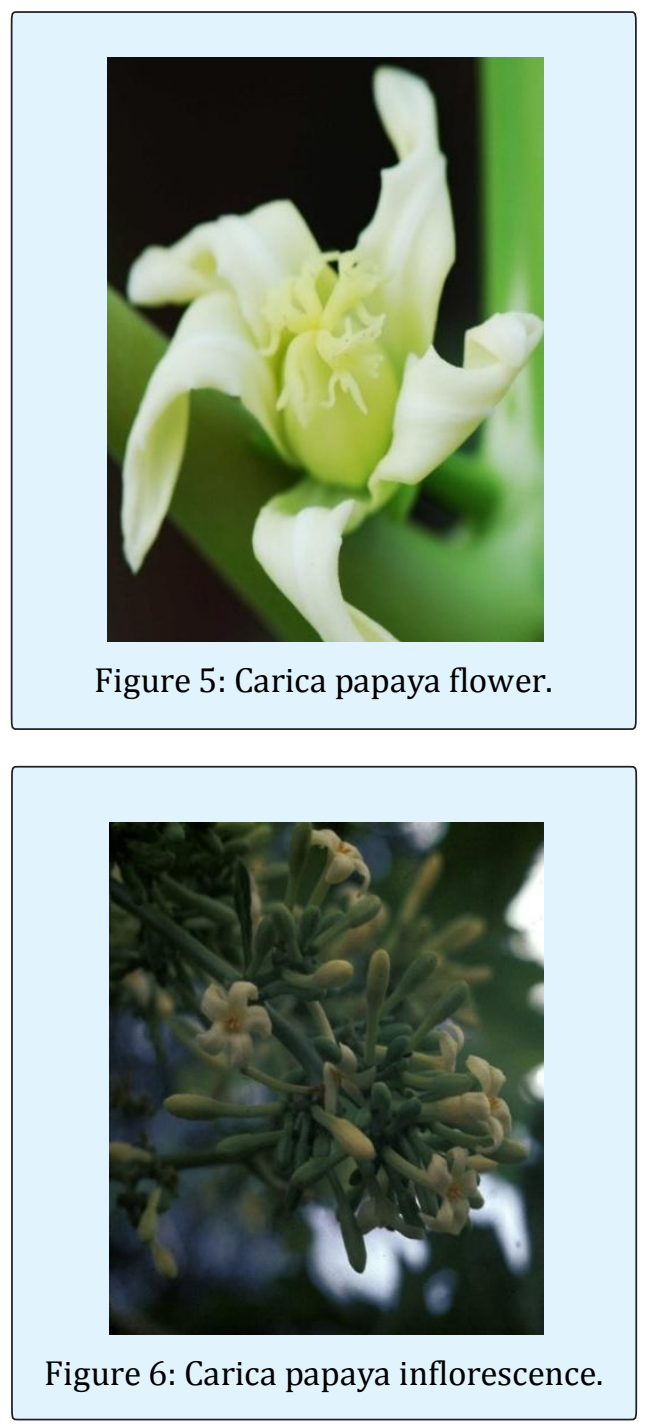

Basalingappa KM, et al. Medicinal Uses of Carica Papaya. J Nat Ayurvedic Med 2018, 2(6): 000144.
Copyright@ Basalingappa KM, et al. 


\section{Journal of Natural \& Ayurvedic Medicine}

- The fruit is ripe when it feels soft (like a ripe avocado or a bit softer) and its skin has attained amber to orange hue. The melon-like fruit varies in size and shape [2]. The fruit is oval to round nearly pyri form or elongated club shaped, $15-50 \mathrm{~cm}$ long and $10-20 \mathrm{~cm}$ thick and $9 \mathrm{~kg}$ weight, semi wild (naturalized) plants possess 2.5 to $15 \mathrm{~cm}$ length, fruit skin is waxy thin and tough.

- Immature fruit which is green in colour contain white latex in more amount on ripening process fruits skin starts turning yellow- orange colour to red, becomes aromatic, juicy and sweet [26].

- The fruit hangs from short, thick peduncles at the leaf axil [2]. The changed in outer colour of the skin of fruit is an indicator of ripeness, and this change is considered mainly due to an increase in the carotene content and a decrease in chlorophyll. Red flesh colour indicated the lycopene content in fruit [27].

\section{Therapautic and Medicinal Values}

\section{Flower}

- Its flowers are mostly dioecious and resemble each other until they start to develop sexual organs. The species is polygamous and can be classified into three sex types: male staminate, hermaphroditic (bisexual) and female pistillate [2].

- Male flowers are in crowded clusters, straw-coloured, and fragrant. Corolla tube is slender, about 2 centimetres long. Female flowers are in short, axillary spikes or racemes, the petals 7 centimetres long or less [28].

- Flowers are used to treat jaundice and have Emmengogue, febrifuge and pectoral properties $[2,23]$. Research done on papaya flower is less, male flowers are checked for their potential to act as herbal tea which acts as a dietary supplement for consumption [29] (Figure 7-9).

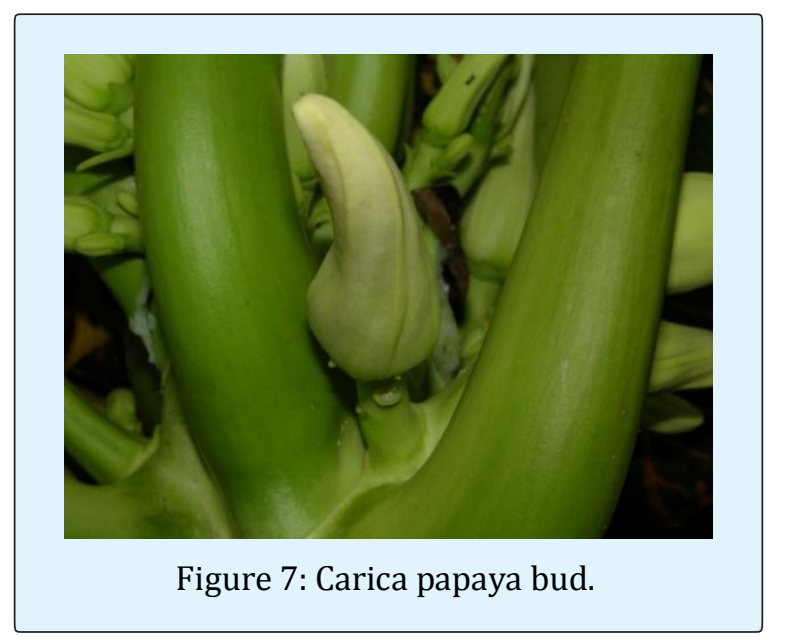

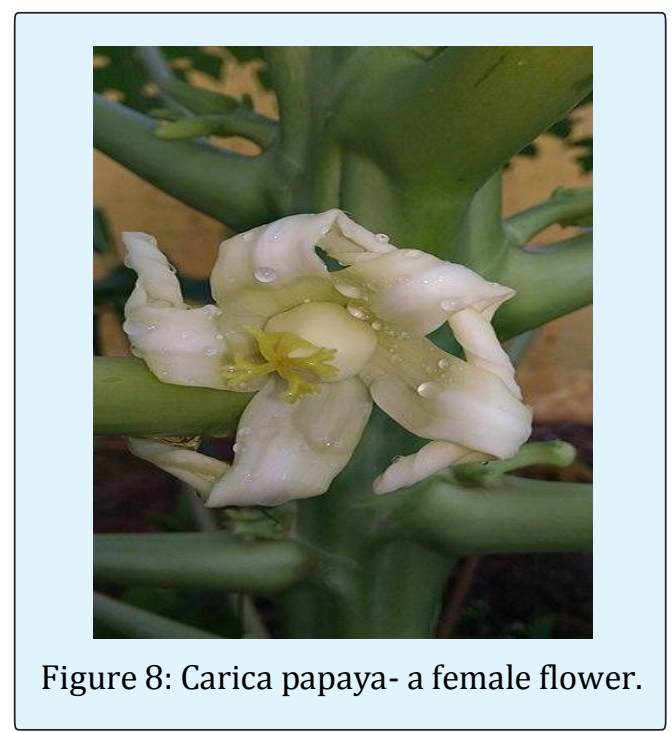

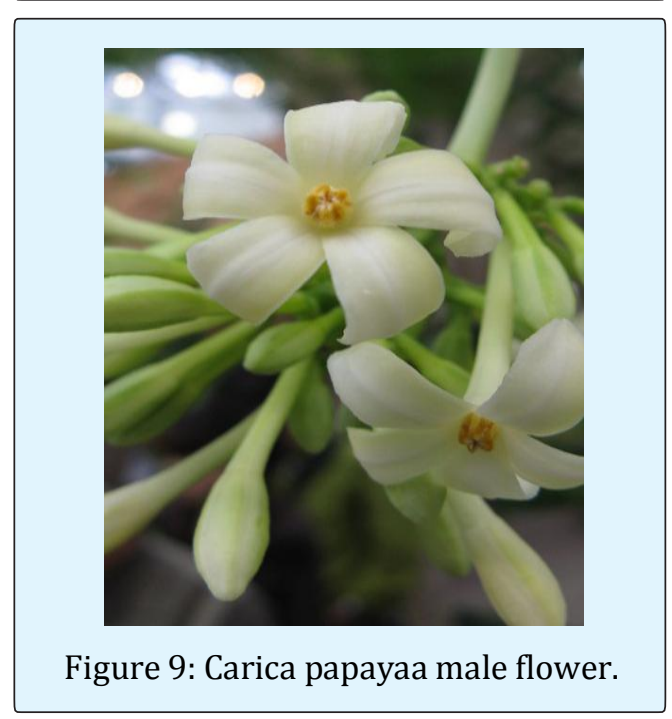

\section{Fruit}

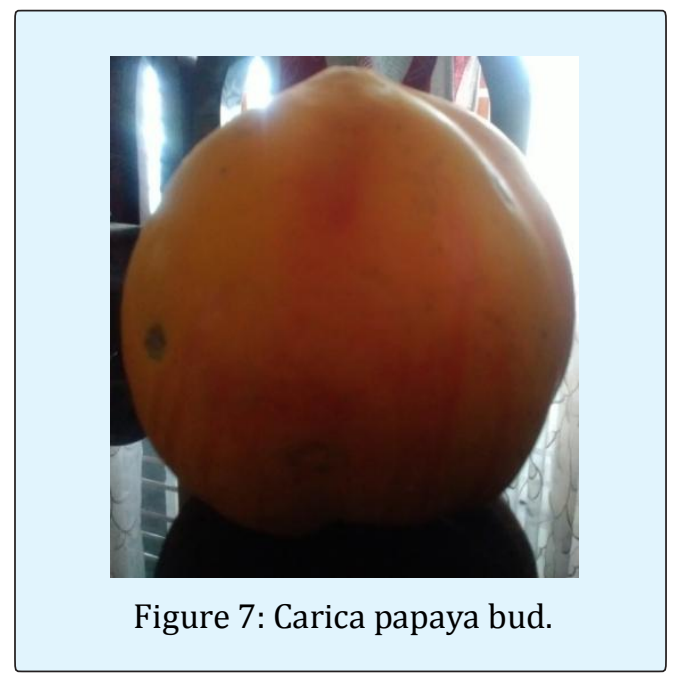




\section{Journal of Natural \& Ayurvedic Medicine}

- Fruit is indehiscent, subglobose, obovoid or oblongcylindric, 5 to 30 centimetre long, fleshy and yellowish or yellow-orange [28] (Figure 10).

- Papain, aprotein is present in unripe fruit which aids in digestion of proteineous materials in food both in acidic, alkaline and neutral medium. Papaya fruit is of high nutritive value and it has low calories of $(32$ $\mathrm{kcal} / 100 \mathrm{~g}$ of ripe fruit) [30]. It is a berry type fruit with parietal plancentation [10].

- Papaya possesses anthelmintic, antiprotozoan, antibacterial, antifungal, antiviral, anti-inflammatory, free-radical scavenging, antisickling, neuroprotective, diuretic, abortifacient, hypoglycemic and hypolipidemic, antihypertensive, wound healing, antitumor and antifertility activities.

- The ripe papaya is used as topical ulcer dressings to promote granulation, healing, and reducing odour in chronic skin ulcers. Green papaya is used for malaria, hypertension, diabetes mellitus, jaundice, intestinal helminthiasis [27].

- It also acts as anti-cancer, stroke prevention and blood cholesterol control [31].

- Papaya contains phytochemicals including polysaccharides, vitamins, minerals, enzymes, proteins, alkaloids, glycosides, fats and oils, lectins, saponins, flavonoids, and sterols [30].

- It is also used in pies, sherbet and salads preparation, jellies, jams, drinks, ice creams as a dried and crystallized fruit [30].

- Papaya is a good source of in Vitamin C, Vitamin A, Calcium, Riboflavin, Folate, Calcium, Thiamine, Iron, Niacin, Potassium and Fibre [30].

- It is also used in tenderizing meat. Papaya also increases the absorption of iron in human biological system papaya fruit contain an alkaloid carpaine having depressant action on the heart [30].

\section{Seed}

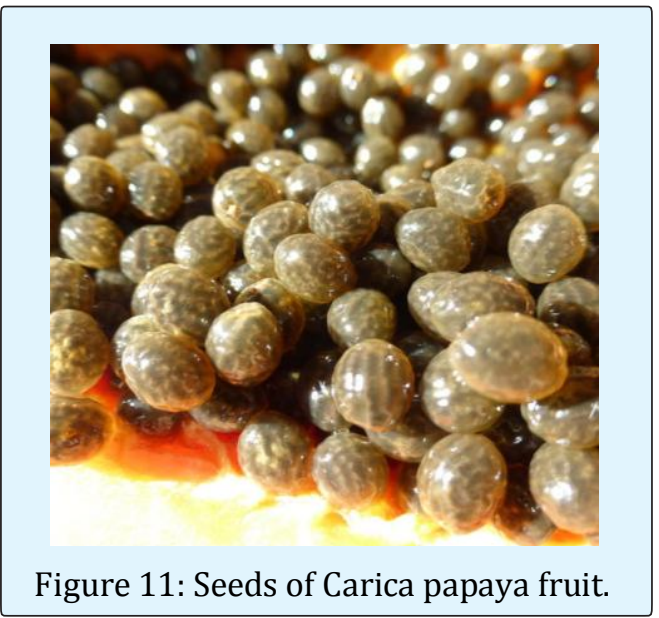

- Seed are black and are present in many numbers; they are embedded in the sweet pulp of ripe fruits [28] (Figure 11).

- Seeds taste like pepper and powdered seeds are used as pepper [18].

- Seeds have pharmacological activities like anthelmintic, antifertility, contraceptive, anti-inflammatory, analgesic and antimicrobial property [9].

- The seed extract is also used as vermifuge, thirst quencher, or pain alleviator seed is used against internal worms when chewed [27,29].

- They are Carminative, emmenagogue, abortifacient, counterirritant, as paste in ringworm disease, psoriasis, anti fertility agent in males.

- Seed juice also used to treat Bleeding piles and in large liver and spleen [2].

- C. papaya seeds protect fibroblasts from H2O2-induced stress due to the antioxidant activity of the water extract [32].

- Also used in the treatment of hypertension, diabetes mellitus and hypercholesterolemia

- The seed has been shown to be a good source of oil $(25.6 \%)$ that may be useful for medicinal, bio fuel and industrial purposes [33].

- The seeds are medicinally important in the treatment of sickle cell disease, poisoning related disorder [34].

Peel

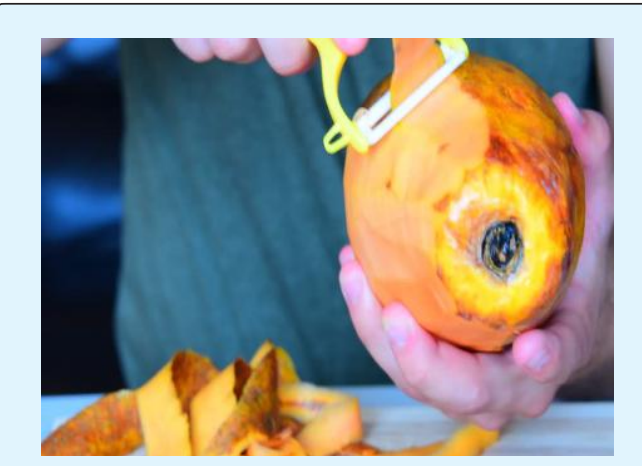

Figure 12: Carica papaya fruit peel.

- Dried Papaya fruit skin serves as a dietary ingredient for poultry feed [30]. Error! Bookmark not defined.The peel extracts function for bio-reduction of silver ions to yield metallic nanoparticles [35] (Figure 12).

- Papaya peel extracts showed antibacterial properties anti-oxidant activity, anti-cancer activity and induced apoptosis [36-38]. 


\section{Journal of Natural \& Ayurvedic Medicine}

- The phytochemical of C. papaya peel extracts can be well utilized for preparing biocides or insecticidal formulation. Peel of C. papaya might be the reason for its larvicidal activity against Aedes aegypti [33].

- Papaya peel too possesses wound healing properties [34].

- papaya peel flour fortified cookies was prepared of specific formulation is found suitable for its better nutritional value as well as sensory characteristics in comparison to other formulated cookies [39].

\section{Leaves}

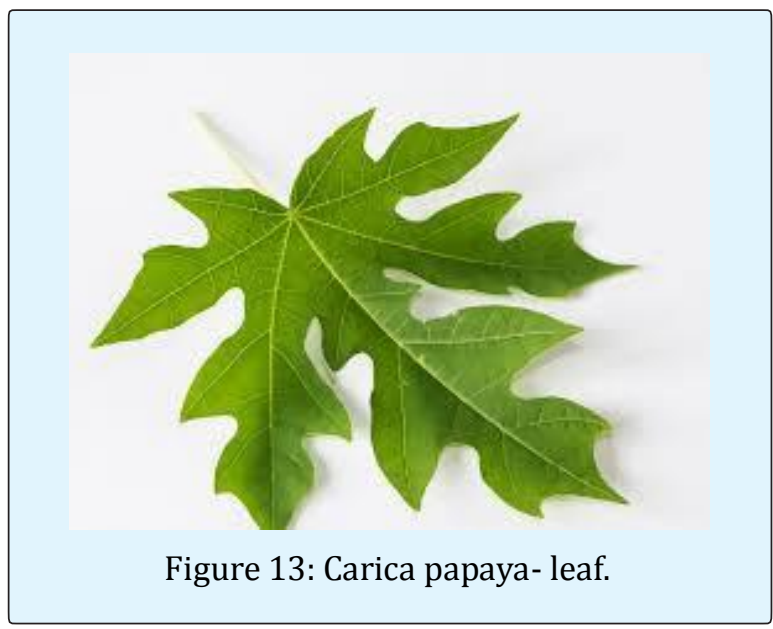

- The hollow green or deep purple trunk is straight and cylindrical with prominent leaf scars. Its diameter may be from 2 or 3 inches to over a foot at the base. Trunk is soft and greyish, marked with large petiole-scars where the leaves are born [28] (Figure 13).

- The leaves are used for colic, fever, beriberi, abortion, asthma in India, and cancer in Australia papaya leaves are used traditionally in treatments like jaundice, malaria, dengue immunomodulatory and antiviral activity $[29,40]$.

- Young leaves are rich in flavonoids (kaempferol and myricetin), alkaloids (carpaine, pseudocarpaine, dehydrocarpaine I and II), phenolic compounds (ferulic acid, caffeic acid, chlorogenic acid), the cynogenetic compounds (benzylglucosinolate).

- They have medicinal properties like anti-inflammatory hypoglycaemic, anti-fertility, abortifacient, and hepatoprotective, wound healing, antihypertensive and antitumor activities [12].

- Young leaves are used in cooking and eaten like spinach in East Indies [18]. papaya leaves are used as a tonic for heart disease, treatment for stomach ache, and have antioxidant, anticancer, antiseptic and analgesic property, immunomodulatory, anti tumour, antiplasmodial, antibacterial, anti dengue, also used in treating wounds, burns and malignant tumours $[9,41,42]$.

- Dried leaves are known as blood purifiers and taken as tonic. Papaya leaf tea is used to treat obesity and helps in losing weight and it acts against chronic indigestion, high blood pressure and arteriosclerosis weakening of heart [42]. Fresh leaves are used to cure gastrointestinal problems and hepatic disease and it also acts as anti-inflammatory and natural abortion agent. In India, traditional Siddha medicinal systems prescribe C. papaya L leaf extract to patients with dengue fever symptoms [43].

- Daily consumption of leaves helps to prevent malaria in Indonesia, aqueous extracts of papaya leaves consumption also increases platelets WBC and neutrophils counts ( especially in dengue patients). Dried leaves have been indicated in sickle cell anemia management [44].

\section{Root}

- Its roots can be used as medicine for renal and urinary bladder problem [45] (Figure 14).

- Root is chewed and swallowed for cough, bronchitis and other respiratory disease [29].

- Also acts as abortifacient, diuretic, antifungal activity, also checks irregular bleeding from uterus, piles.

- The roots are used in traditional medicine for treatment of diseases as it could be a good source of drug for birth control in males [46].

- The treatment of gastroenteritis, urethritis, otitis media, typhoid fever and wound infections [47]. It also helps in treating infectious wound, pneumonia internal heat, stomach noise, and strange movement in the body, abdominal pains and a host of other diseases [48].

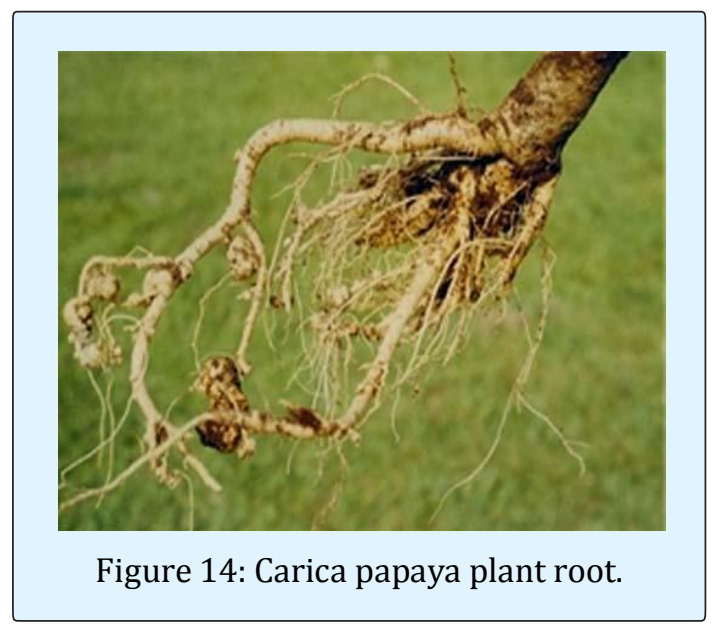




\section{Journal of Natural \& Ayurvedic Medicine}

\section{Stem}

- The stem of Carica papaya shows that it can be potential source of carbohydrate and fibre which can be taken as food and helps to regulate bowel moment.

- It also acts as source of fat when ingested. Stem is a poor source of ash and protein which indicates it can be stored for longer duration [49].

- The bark and twig tissues are found to possess antitumour and pesticidal properties [29] (Figures 15 \& 16) (Tables $2 \& 3$ ).

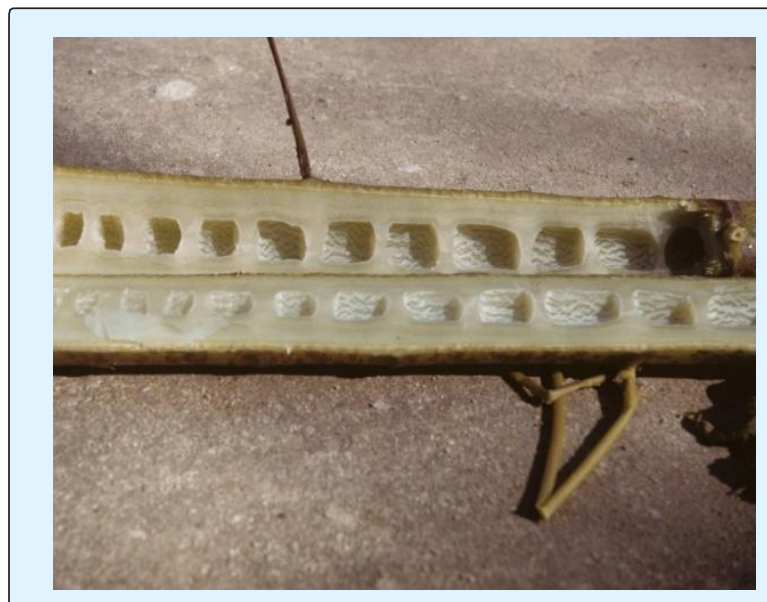

Figure 15: Carica papaya Vertical section stem.

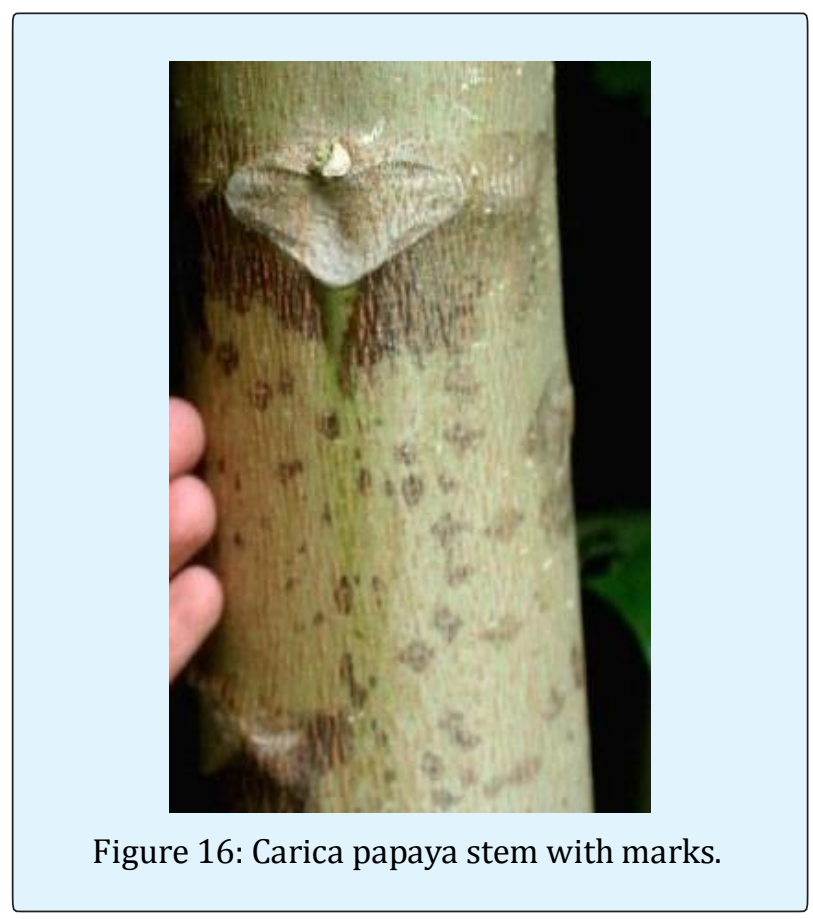

\begin{tabular}{|c|c|c|c|c|c|c|}
\hline & Zn & Fe & Ca & K & Na & Mg \\
\hline Root & 23.91 & 8.14 & 186.64 & 781.44 & 63.68 & 23.16 \\
\hline Stem & 31.05 & 7.73 & 262.18 & 775.12 & 87.08 & 27.71 \\
\hline Leaf & 10.97 & 6.07 & 628.63 & 316.40 & 17.72 & 10.64 \\
\hline Fruit & 0.28 & 2.73 & 153.91 & 711.23 & 26.31 & 0.84 \\
\hline Seed & 23.91 & 8.14 & 186.64 & 781.44 & 63.68 & 23.16 \\
\hline
\end{tabular}

Table 2: Estimation of nutritionally important minerals in different plant parts of Carica Papaya (in ppm) [50].

\begin{tabular}{|c|c|c|}
\hline & Phytoconstituents & Part of plant \\
\hline 1 & Enzyme Papain, chymopapain & Unripe fruit \\
\hline 2 & Carotenoids B carotene, Crytoxanthin & fruits \\
\hline 3 & Carposide & roots \\
\hline 4 & $\begin{array}{c}\text { Glucosinolates Benzyl isothiocyanate, } \\
\text { papaya oil }\end{array}$ & seeds \\
\hline 5 & Minerals Ca, K, Mg, Zn, Mn, Fe & $\begin{array}{c}\text { Shoots, } \\
\text { leaves }\end{array}$ \\
\hline 6 & Flavonoids Mycricetin, kaempferol & shoots \\
\hline 7 & $\begin{array}{c}\text { Alkaloids Carpaine, Carpinine, Vitamin C } \\
\text { and B }\end{array}$ & Leaves \\
\hline 8 & Monoterpenoids Linalool, 4-terpinol & fruits \\
\hline
\end{tabular}

Table 3: Chemical constituents present in different parts of papaya plant [51].

\section{Conclusion}

Carica papaya is a tropical and sub-tropical plant belongs to Caricaceae family, it is a perennial herb having life span of about 20 years, each and every part of papaya plant is useful as a diet and also as medicinal purposes like leaves, fruit, peel, flower, stem and root. It has having wide variety of nutrients, mineral, enzymes and other chemical constituents which play a very important role in medicinal uses. Having its origin in Central America is now grown as commercial crops in other countries. Carica papaya being used as antioxidant, anti-inflammatory, anti diabetic, antifungal, anticancer, antihelminthic, healing etc.

\section{References}

1. Suresh K, Deepa P, Harisaranraj R, Achudhan VV (2008) Antimicrobial and Phytochemical Investigation of the Leaves of Carica papaya $\mathrm{L}$, Cynodon dactylon (L) Pers, Euphorbia hirta L, Melia azedarach L, and Psidium guajava L, Ethnobotanical Leaflets 2008(1): 1-8. 


\section{Journal of Natural \& Ayurvedic Medicine}

2. Roshan A, Verma NK, Gupta A (2014) A Brief Study on Carica Papaya- A Review. International Journal of Current Trends in Pharmaceutical Research 2(4): 541-550.

3. Lohidas J, Manjusha S, Jothi GGG (2015) Animicrobial activity of Carica Papaya L. Plant Archives 15(2): 1179-1186.

4. Srivastava AK, Singh VK (2016) Carica Papaya- A Herbal Medicine. International Journal of Research Studies in Biosciences (IJRSB) 4(11): 19-25.

5. Sudhakar N, Vidhya (2014) TRM Potential medicinal properties of carica papaya linn.- A mini review. International Journal of Pharmacy and Pharmaceutical Sciences 6(2): 1-4.

6. Ayoola PB, Adeyeye A (2010) Phytochemical and nutrient evaluation of Carica papaya (paw paw) leaves. IJRRAS 5(3): 325- 328.

7. Lydia E, Riyazudin M, John S, Priya ST (2016) Investigation on the phytochemical present in the fruit peel of Carica papaya and evaluation of its antioxidant properties. International Journal of Health Allied Sciences 5(4): 247-252.

8. Carica Papaya, Florida plant encyclopedia -902.

9. Agarwal A, Vyas S, Agarwal DP (2016) Therapeutic benefits of Carica papaya leaf extracts in dengue fever patients. Scholars Journal of Applied Medical Sciences (SJAMS) 4(2A): 299-302.

10. Noshad Q Anjum M (2018) Investigations of phytochemical and antifungal activity of Carica papaya L leaves. Pure Appl Biol 7(1): 309-314.

11. Radhakrishnan N, Lam KW, Norhaizan ME (2017) Molecular docking analysis of Carica papaya Linn constituents as antiviral agent. International Food Research Journal 24(4): 1819-1825.

12. Yogiraj V, Goyal PK, Chauhan CS, Goyal A, Vyas B (2014) Carica papaya Linn: An Overview. International Journal Herbal Medicine 2(5): 1-8.

13. Dharmarathna SL, Wickramasinghe S, Waduge RN Rajapakse RP, Kularatne SA (2013) Does Carica papaya leaf-extract increase the platelet count? An experimental study in a murine model. Asian Pac J Trop Biomed 3(9): 720-724.
14. Jaiswal P, Kumar P, Singh VK, Singh DK (2010) Carica papaya Linn: A Potential source for various health problems. Journal of Pharmacy Research 3(5): 9981003.

15. Nordin NDB (2010) The extraction of papain from papaya leaves. A thesis submitted in fulfilment of the requirements for the award of the degree of Bachelor of Chemical Engineering (Biotechnology).

16. Nugroho A, Heryani H, Choi JS, Park HJ (2017) Identification and quantification of flavonoids in Carica papaya leaf and peroxynitrite scavenging activity. Asian Pacific Journal Tropical Biomedicine 7(3): 208-213.

17. Uduak UE, Timbuak JA, Musa SA, Asala S, Hambolu J, et al. (2013) Acute and Chronic Hepatotoxicity and Nephrotoxicity Study of Orally Administered chloroform extract of Carica papaya Seeds in Adult Wistar Rats. International Journal of Scientific and Research Publications 3(4): 1-8.

18. The Biology of Carica papaya L. (papaya, papaw, paw paw) (2008) Office of the Gene Technology Regulator.

19. The Biology and Ecology of Papaya (paw paw) (2003) Carica papaya L, in Australia Office of the Gene Technology Regulator.

20. Begum M (2014) phytochemical and pharmacological investigation of Carica papaya EWU Institutional Repository.

21. Biology of Carica papaya (Papaya)-series of crop specific biology documents. Ministry of Environment, Forest and Climate Change (MoEF\&CC) and Indian Institute Horticulture Research, Bengaluru pp: 1-32.

22. Renner SS, Heubl G (2013) Molecular phylogeny, biogeography, and an e-monograph of the papaya family (Caricaceae) as an example of taxonomy in the electronic age. Gutachter.

23. Sharma DK, Tiwari B, Singh RK, Sahu S, Mathur SC, et al. (2013) Estimation of Minerals in Carica papaya L. Leaf found in Northern India by using ICP-OES Technique. International Journal Scientific Engineering Research 4(6): 1012.

24. Wijaya HC, Chen F (2013) Flavour of papaya ( L.) Carica papaya. Biotropia 20(1): 50-71. 


\section{Journal of Natural \& Ayurvedic Medicine}

25. Nishina M, Zee F, Ebesu R, Arakaki A, Hamasaki R, et al. (2000) Papaya Production in Hawaii Cooperative Extension Service. Fruits and Nuts F\&N-3.

26. Jaime A, Silva TD, Rashid Z, Nhut DT, Shivakumar D, et al. (2007) Carica papaya ( Carica papaya L.) biology and biotechnology. Tree and forestry science and biotechnology 1(1): 47-73.

27. Maisarah AM, Asmah R, Fauziah O, AnalysisP, Antioxidant and Antiproliferative Activities of Different Parts of Carica Papaya. Journal of Nutrition \& Food Sciences 4(2): 1-7.

28. Stuart GU (2017) StuartXchange. Philippine medicinal plants.

29. Bergonio KB, Perez MA (2016) The potential of male papaya (Carica papaya L.) flower as a functional ingredient for herbal tea production. Indian journal traditional knowledge 15(1): 41-49.

30. Adiaha MS, Adiaha MS (2017) Effect of Nutritional, Medicinal and Pharmacological Properties of Papaya (Carica papaya Linn.) to Human Development: A Review. WSN 67(2): 238-249.

31. Arliana F, Tunjung, Anindito W (2013) The flavonoids content in leaves and fruits of papaya (Carica papaya L.) var. Gandul. Knowledge E life sciences 2(2015): 154-158.

32. Panzarini E, Dwikat M, Mariano S (2014) Administration Dependent Antioxidant Effect of Carica papaya Seeds Water Extract. Evidence-Based Complementary and Alternative Medicine 2014: 13.

33. Hayatie L, Biworo A, Suhartono E (2015) Aqueous Extracts of Seed and Peel of Carica Papaya against Aedes Aegypti. Journal of Medical and Bioengineering 4(5): 417-421.

34. Parni B, Verma Y (2014) Biochemical properties in peel, pulp and seeds of Carica papaya. Plant Archives 14(1): 565-568.

35. Prasad CH, Srinivasulu K, Venkateswarlu P (2015) Catalytic Reduction of 4-Nitrophenol Using Biogenic Silver Nanoparticles Derived from Papaya (Carica papaya) Peel extract. Industrial Chemistry 1(1): 1-4.

36. Muhamad SAS, Jamilah B, Russly AR, Faridah, A (2017) In vitro antibacterial activities and composition of Carica papaya CV Sekaki/Hong Kong peel extracts. International Food Research Journal 24(3): 976-984.

37. Dada FAB, Nzewuji FOZ, Esan AM, Oyeleye SI (2016) Phytochemical and antioxidant analysis of aqueous extracts of unripe papaw (Carica papaya Linn.) fruit's peel and seed. IJRRAS 127(3): 68-71.

38. Salla S, Sunkara R, Walker LT, VergheseM (2016) Antioxidant and Apoptotic Activity of Papaya Peel Extracts in HepG2 Cells. Food and Nutrition Sciences 7: 485-494.

39. Bokaria K, Ray S (2016) Development of papaya peel flour based cookies and evaluation of its quality. Journal of Multi-disciplinary Engineering Science and Technology (JMEST) 3(12): 6393- 6397.

40. Kavimandan B, Saraf M (2016) Studies on Biological Efficacy of Various Leaf Extracts of Carica Papaya L. International Conference on Global Trends in Engineering, Technology and Management pp: 510516.

41. Ghori NUH (2013) Antioxidant potential and anticancer activity of different extracts from leaves of papaya (Carica papaya), Institute of molecular biology and Biotechnology, The University of Lahore.

42. Nugroho A, Heryani H, Choi JS , Park HJ (2017) Identification and quantification of flavonoids in Carica papaya leaf and peroxynitrite-scavenging activity. Asian Pacific Journal of Tropical Biomedicine 7(3): 208-213.

43. Joseph B, Sankarganesh P, Ichiyama K, Yamamoto N (2015) In vitro study on cytotoxic effect and antiDENV2 activity of Carica papaya L. leaf. Frontiers in Life Science 8(1): 18-22.

44. Imaga NA, Adepoju OA (2010) Analyses of anti sickling potency of Carica papaya dried leaf extract and fractions. Journal of Pharmacognosy Phytotherapy 2(7): 97-102.

45. Romasi EF, Karina J, Parhusip AJ (2011) Antibacterial effects of papaya leaf extracts against pathogenic bacteria. Makara Teknologi 15(2): 173-177.

46. Nwaehujora CO, Odeb JO, Ekwerea MR, Udegbunamc RI (2014) Anti-fertility effects of fractions from Carica papaya (Pawpaw) Linn. methanol root extract in male Wistar rats. Arabian Journal Chemistry pp: 18785352. 


\section{Journal of Natural \& Ayurvedic Medicine}

47. Doughari JH, Elmahmood AM, Manzara S (2007) Studies on the antibacterial activity of root extracts of Carica papaya L. African Journal Microbiology Research pp: 37-41.

48. Chinonye II, Cynthia O, et.al, (2016) Phytochemicals and Antimicrobial Properties of the Root and Leaf Extract of Carica Papaya. Internartional journal of innovative research and development 5(8): 175- 179.

49. Stephen C, Ukpabi C, Tochukwu. E, Nkwach B (2013) Chemical composition of Carica Papaya stem (pawpaw). American Open Food Science Journal 1(1): $1-5$.

50. Verma SK, Kaushal SV (2014) Nutritive assessment of different plant parts of Carica papaya Linn of Jabalpur region. Scholars Research Library 4 (1): 52-56.

51. Aravind G, Bhowmik D, Duraivel S, Harish (2013) Traditional and Medicinal Uses of Carica papaya. Journal of Medicinal Plants Studies 1(1): 1-9.

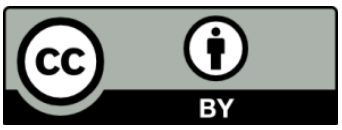

